\title{
NEW CLADID AND FLEXIBLE CRINOIDS FROM THE MISSISSIPPIAN (TOURNAISIAN, IVORIAN) OF ENGLAND AND WALES
}

\author{
by THOMAS W. KAMMER* and WILLIAM I. AUSICH $\dagger$ \\ *Department of Geology and Geography, West Virginia University, Morgantown, WV 26506-6300, USA; e-mail: tkammer@wvu.edu \\ $†$ †chool of Earth Sciences, 155 South Oval Mall, The Ohio State University, Columbus, OH 43210, USA; e-mail: ausich.1@osu.edu \\ Typescript received 8 March 2006; accepted in revised form 11 August 2006
}

Abstract: The modern study of fossil crinoids began with J. S. Miller who, in 1821, described specimens from southern England, nearby Wales and other regions, and named several common Early Carboniferous genera. Later, in 1950-60, James Wright monographed all known Early Carboniferous crinoids from the British Isles. In spite of such previous scrutiny, we recognize here two new genera among species already described: Glamorganocrinus gen. nov. (type species: Ophiurocrinus gowerensis Wright, 1960) from South Wales and Mendipocrinus gen. nov. (type species: Poteriocrinus latifrons Austin and Austin, 1847) from southern England. These new genera increase the number of advanced cladid genera in the Ivorian Substage of the Tournaisian in western Europe to 18 , and the total number of crinoid genera to 36 . A review of species assigned to Mespilocrinus has led to the recognition of M. granulifer De Koninck and LeHon, 1854 as a nomen dubium. A new species of Mespilocrinus, M. wrighti sp. nov., is described from the Ivorian of South Wales; this is the most highly derived species of the genus, as based on a phylogenetic analysis including ten species and 13 characters, with Pycnosaccus as the outgroup. A single, well-ordered tree resulted from this analysis. Interpretation of this tree suggests that the centre of evolution for Mespilocrinus was North America, where three species appeared during the Kinderhookian (early Tournaisian), rapidly achieving morphological disparity within the genus. This radiation event was part of the overall explosive radiation of crinoids following the Late Devonian mass extinction event when crinoid diversity was at a global minimum during the Frasnian. Recovery began during the Famennian, followed by an explosive radiation in the Tournaisian.

Key words: Crinoids, new taxa, Mississippian, Tournaisian, England, Wales.
THE first modern work on crinoids was 'A natural history of the Crinoidea or lily shaped animals' by J. S. Miller (1821). In this work, the author defined the Crinoidea as they are presently understood, i.e. a group of echinoderms separate from starfish and including both stalked and unstalked forms. The primary focus of Miller's treatise was on Early Carboniferous and Jurassic crinoids from England, particularly from the Somerset/Avon region, but it also included material from Lancashire/Yorkshire, South Wales (Caldy Island) and southern Ireland. Miller (1821) defined Early Carboniferous crinoid genera that are among the most characteristic and cosmopolitan crinoids worldwide in that time interval: Actinocrinites, Cyathocrinites, Poteriocrinites, Platycrinites and Rhodocrinites.

More recently, James Wright published numerous contributions between 1911 and 1960, with his comprehensive monograph on Carboniferous crinoids (Wright 1950-60) being the most significant. Wright redescribed and summarized all Carboniferous crinoids known from England, Scotland, Wales and Ireland. This monograph showcased Wright's keen skill as a collector, and it reflected the understanding of crinoids and the application of specific and generic concepts during the middle part of the twentieth century. Since Wright completed his work, relatively few studies have dealt directly with Early Carboniferous crinoids from England and Wales. Among those that have are Westhead (1979), Donovan and Sevastopulo (1985, 1988), Donovan (1986, 1992), Donovan and Westhead (1987), Donovan and Veltkamp (1990), Donovan et al. (2005) and Ausich and Sevastopulo (2001), who revised the crinoid fauna at Hook Head, County Wexford, Ireland, including equivalent faunas in South Wales and the Avon/Somerset region.

The present contribution is part of a larger study on the global evolutionary palaeoecology of Early Carboniferous, or Mississippian (Heckel and Clayton 2005), crinoids. Prerequisite to this macroevolutionary analysis is 
establishment of accurate generic concepts, facies distributions and temporal ranges of genera. These data will be used to test the relationships between generic longevity, eurytopy (environmental breadth) and geographical range within and between the various crinoid clades in order to assess the patterns of evolutionary success and failure among Late Palaeozoic crinoids. As part of this study, all known species and genera of Mississippian crinoids from western Europe have been reviewed, and type specimens have been observed directly in museum collections where possible, in order to assess correct generic assignment.

Herein, we report on two new genera recognized from among previously described species: Glamorganocrinus gen. nov. and Mendipocrinus gen. nov., and describe a new species, Mespilocrinus wrighti sp. nov. All three new taxa are from the Ivorian Substage of the Tournaisian Stage, being close in age to the Hook Head crinoid fauna (Ausich and Sevastopulo 2001), but possibly slightly younger (Mitchell et al. 1986). These new genera bring the total crinoid generic richness of the Ivorian of Western Europe to 36, 18 of which are advanced cladids (Ausich and Kammer 2006).

\section{SYSTEMATIC PALAEONTOLOGY}

Terminology follows Ubaghs (1978), and higher-order taxonomy follows Moore and Teichert (1978), with modifications by Simms and Sevastopulo (1993) and Ausich (1998). Specimen numbers bear the following institutional prefixes: GSM, the Geological Survey Museum, British Geological Survey, Keyworth; NMW, the National Museum of Wales, Cardiff; BMNH, the Natural History Museum, London; NMS, National Museums of Scotland, Edinburgh.

\section{Class CRINOIDEA Miller, 1821 \\ Subclass CLADIDA Moore and Laudon, 1943 Order DENDROCRINIDA Bather, 1899}

Remarks. We follow McIntosh (2001) in placing pinnulate cladid crinoids in the order Dendrocrinida, which contains both pinnulate and non-pinnulate taxa. The Poteriocrinida as defined by Moore et al. (1978) is probably a polyphyletic grouping composed of several pinnulate taxa derived from the Dendrocrinida sensu Moore et al. (1978).

Family SCYTALOCRINIDAE Moore and Laudon, 1943

Genus GLAMORGANOCRINUS gen. nov.

Derivation of name. After the Vale of Glamorgan, Wales.
Type species. Ophiurocrinus gowerensis Wright (1960).

Diagnosis. Crown slender, five arms total; cup low-bowl shape with medium-thick plates, wider than high; infrabasals very small, nearly covered by column; basals slightly wider than high; radials wider than high with plenary facets; anal sac long and slender, composed of smooth, hexagonal plates; arms composed of short, wide brachials that resemble columnals in aboral view.

\section{Glamorganocrinus gowerensis (Wright, 1960) Text-figure 1F-G; Table 1}

1960 Ophiurocrinus gowerensis Wright, p. 329, appendix, pl. A, figs 7-8.

Types. Holotype, GSM 85252, a complete crown preserving the anal sac. Paratype, GSM 85251A, a partial crown.

Description. Crown slender. Aboral cup low bowl-shaped with a convex base, height to width ratio approximately $0 \cdot 4$; plates smooth, lacking ornamentation, slightly tumid with distinct sutures; infrabasals very small, slightly visible in side view; basals hexagonal, slightly wider than high, height to width ratio approximately $0 \cdot 8$; radials pentagonal, wider than high, height to width ratio approximately $0 \cdot 6$, with plenary facets. Three anal plates in cup; radianal largest; anals arranged in typical advanced cladid arrangement with anal $\mathrm{X}$ to the left of and above the radianal, and a space for the right tube plate, which is missing but the outline is clear, above the radianal. Anal sac elongate, originally about twice as long because the distal portion is folded behind the proximal portion; composed of smooth, hexagonal plates, no evidence of pores along sutures. Arms five, atomous in all rays; brachials wider than long, rectangular, resemble columnals in aboral view; pinnules present, one per brachial, robust. Column circular, heteromorphic with distinct nodals and internodals.

Remarks. Wright's (1960, appendix pl. A, fig. 7) illustration of the holotype has inked-in plate boundaries for both the aboral cup and the anal sac. The plate boundaries on the lower half of the anal sac and the anal plates above the anal $\mathrm{X}$ must have been inferred by Wright as these plates are not preserved (Text-fig. 1F). The radianal, anal $\mathrm{X}$ and right tube plates are the primanal, secundanal and tertanal, respectively, of Webster and Maples (2006).

Comparisons. Glamorganocrinus gen. nov. has five atomous arms with rectangular brachials similar to those of Ophiurocrinus Jaekel, 1918. Although the arms are similar to those of Ophiurocrinus, the aboral cup is distinctly bowl-shaped rather than conical. The cone-shaped cup of Ophiurocrinus has high infrabasals clearly visible in side 

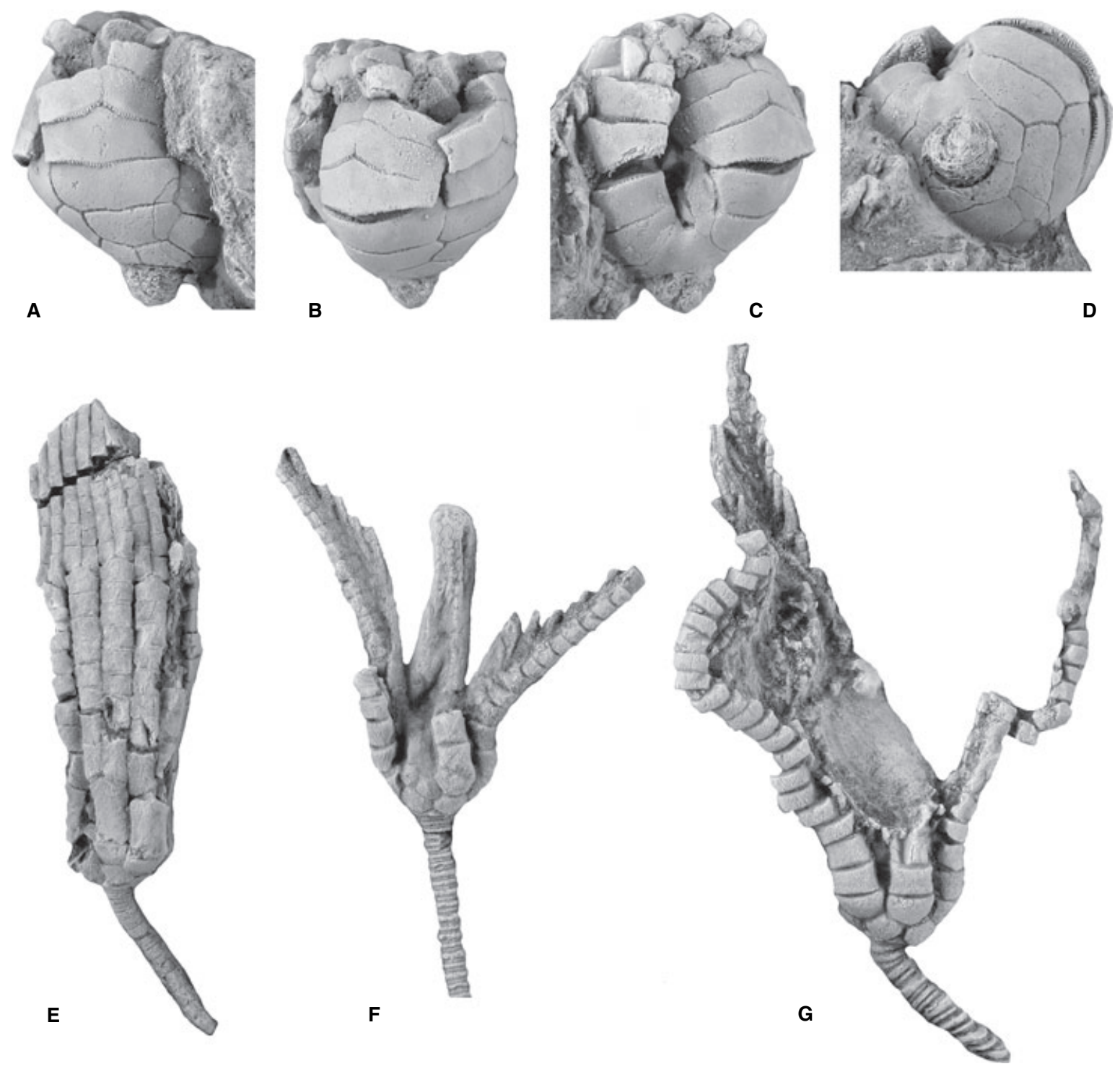

TEXT-FIG. 1. A-D, Mespilocrinus wrighti sp. nov., NMW 81.8G.6825, holotype, Blucks Pool Limestone, Bosherton area, near Linney Head, Pembrokeshire. A, B ray view. B, C ray view. C, C-D interray view. D, aboral view with C-D interray at top. E, Mendipocrinus (gen. nov.) latifrons (Austin and Austin, 1847), GSM 7603, holotype, Black Rock Limestone, Mendip Hills, Somerset, B ray view. F-G, Glamorganocrinus (gen. nov.) gowerensis (Wright, 1960), Penmaen Burrows Limestone Group, Three Cliffs Bay, Gower, West Glamorgan. F, GSM 85252, holotype, posterior view; the two long arms are the B and E rays. G, GSM 85251A, paratype, anterior view. All $\times 3$.

TABLE 1. Measurements (in $\mathrm{mm}$ ) of Glamorganocrinus (gen. nov.) gowerensis (Wright, 1960).

\begin{tabular}{|c|c|c|c|c|c|c|}
\hline Ray & $\begin{array}{l}\text { Crown } \\
\mathrm{H}\end{array}$ & $\begin{array}{l}\text { Cup } \\
\mathrm{H}, \mathrm{W}\end{array}$ & $\begin{array}{l}\text { Infrabasal } \\
\mathrm{H}, \mathrm{W} \\
\mathrm{C}\end{array}$ & $\begin{array}{l}\text { Basal } \\
\mathrm{H}, \mathrm{W} \\
\mathrm{BC}\end{array}$ & $\begin{array}{l}\text { Radial } \\
\mathrm{H}, \mathrm{W} \\
\mathrm{C}\end{array}$ & $\begin{array}{l}\text { Arms } \\
\mathrm{L}\end{array}$ \\
\hline \multicolumn{7}{|c|}{ GSM 85252, holotype } \\
\hline & $19 \cdot 3$ & $2 \cdot 4,5 \cdot 5$ & $0 \cdot 5,1 \cdot 2$ & $1 \cdot 7,2 \cdot 1$ & $1 \cdot 3,2 \cdot 0$ & $15 \cdot 6$ \\
\hline \multicolumn{7}{|c|}{ GSM 85251 A, paratype } \\
\hline & $21 \cdot 7$ & $2 \cdot 7,6 \cdot 4$ &,-- & $1 \cdot 7,2 \cdot 0$ & $1 \cdot 6,2 \cdot 5$ & 21 \\
\hline
\end{tabular}

view (Moore et al. 1978), unlike the almost hidden infrabasals of Glamorganocrinus.

Glamorganocrinus is placed in the Scytalocrinidae because this family includes other five-armed genera with plenary radial facets such as Ophiurocrinus, Gilmocrinus Laudon, 1933 and Anemetocrinus Wright, 1938, all of which have a cone-shaped cup. Most genera in the Scytalocrinidae have cone-shaped cups, although the type genus, Scytalocrinus Wachsmuth and Springer, 1880, has a bowl-shaped cup like Glamorganocrinus (Moore et al. 
1978). Gilmocrinus not only has a bowl-shaped cup, but also elongate, subcuneate brachials (Kammer et al. 2007). Anemetocrinus has biserial arms (Moore et al. 1978).

Occurrence. Penmaen Burrows Limestone Group, Three Cliffs Bay, Gower, West Glamorgan (British Grid ref. SS 535 881). Wright (1960, p. 329) recorded the horizon as $Z$ zone of Vaughan's (1905) coral zonation, which is of Ivorian or late Courceyan age (Leeder 1992). Upper Courceyan rocks of the Penmaen Burrows Limestone Group include the Shipway Limestone and Tears Point Limestone, both of which were deposited in a middle to outer ramp succession (Adams et al. 2004). Presumably, Glamorganocrinus gowerensis was collected from one of these two limestones. Burchette et al. (1990) reported crinoid-rich packstones from the Shipway Limestone. V. P. Wright (pers. comm. 2003) confirmed that the best crinoid material at Three Cliffs Bay is Ivorian in age.

\section{Family PACHYLOCRINIDAE Kirk, 1942}

\section{Genus MENDIPOCRINUS gen. nov.}

Derivation of name. After the Mendip Hills, Somerset, England.

Type species. Poteriocrinus latifrons Austin and Austin, 1847.

Diagnosis. Crown cylindrical, slender; cup low-bowl shape with relatively thin plates, wider than high; infrabasals very small, nearly covered by stem; basals slightly wider than high; radials twice as wide as high with plenary facets; arm branching isotomous, very regular, arms closely abutted; arms branch on primibrachial 1 and a second time on secundibrachial 8; primibrachial 1 very elongate, proximal secundibrachials elongate, distal ones quadrangular, tertibrachials elongate, rectangular.

\section{Mendipocrinus latifrons (Austin and Austin, 1847) Text-figure 1E; Table 2}

1847 Poteriocrinus latifrons Austin and Austin, p. 82, pl. 10, fig. 4.

1878 Scaphiocrinus latifrons (Austin); Sladen, p. 248.

1880 Pachylocrinus latifrons (Austin); Wachsmuth and Springer, p. 116.

TABLE 2. Measurements (in $\mathrm{mm}$ ) of Mendipocrinus (gen. nov.) latifrons (Austin and Austin, 1847); GSM 7603, holotype.

\begin{tabular}{llllll}
\hline Crown & Cup & Infrabasal & Basal & Radial & Arms \\
H & H, W & H, W & H, W & H, W & L \\
Ray & & C & BC & B & \\
\hline $24 \cdot 1$ & $3 \cdot 3,5 \cdot 0$ & $0 \cdot 9,0 \cdot 5$ & $1 \cdot 2,1 \cdot 7$ & $1 \cdot 1,2 \cdot 1$ & $21 \cdot 3$ \\
\hline
\end{tabular}

1886 Woodocrinus latifrons (Austin); Wachsmuth and Springer, p. 242.

1943 Pachylocrinus latifrons (Austin and Austin); Bassler and Moodey, p. 581.

$1951 b$ Pachylocrinus? latifrons (Austin and Austin); Wright, p. 65 , pl. 31 , fig. 5 .

Type. Holotype, and sole specimen known, is a relatively complete crown (GSM 7603).

Description. Crown cylindrical, slender. Aboral cup low bowlshaped with a convex base, height to width ratio approximately 0.67 ; plates thin, smooth, lacking ornamentation; infrabasals very small, slightly visible in side view; basals hexagonal, wider than high, height to width ratio approximately $0 \cdot 7$; radials pentagonal, wider than high, height to width ratio approximately 0.5 , with plenary facets. Apparently three anals as a partial radianal and right tube plate are preserved along with a space for the anal $\mathrm{X}$, which is missing. Anal sac unknown. Arm branching isotomous, very regular, first branching on primibrachial 1, second branching on secundibrachial 8; arms closely abutted. Brachials all rectangular, ranging from elongate to quadrangular; primibrachial 1 elongate, about twice as high as wide; proximal secundibrachials less elongate, distal secundibrachials quadrate; tertibrachials elongate. Pinnules not observed, but arms are tightly closed. Column circular, homeomorphic.

Comparisons. Mendipocrinus differs from true Pachylocrinus Kirk, 1942 (Kammer and Ausich 1993) by having primibrachial 1 axillary, rather than primibrachial 2; primibrachial 1 is unusually elongate; the brachials are rectangular, rather than subcuneate or cuneate; the arms closely abut; the isotomous arm branching is very regular rather than uneven; and the basals are not bulbous and larger than the radials. Mendipocrinus is more similar to Dinotocrinus Kirk, 1941 and Borucrinus Ausich and Sevastopulo, 2001 (like Dinotocrinus, except first branching is higher on the A ray), but both of these genera have subcuneate brachials and narrow arms that do not closely abut. Aphelecrinus Kirk, 1944 differs in having a coneshaped cup, clearly visible infrabasals and subcuneate arms that do not closely abut.

Mendipocrinus is placed in the Pachylocrinidae because it has a low, bowl-shaped cup, infrabasals that are not readily visible in side view, plenary facets, three anals in the cup, and isotomous branching two or more times (Moore et al. 1978; Kammer and Ausich 1993).

Occurrence. Tournaisian (Ivorian), Black Rock Limestone, Mendip Hills, Somerset. The precise locality was not recorded by Austin and Austin (1847), who noted that in their experience this taxon is restricted to the Mendips. The Black Rock Limestone is still a valid stratigraphical term in the Mendip Hills (Adams et al. 2004). 


\author{
Subclass FLEXIBILIA von Zittel, 1895 \\ Order SAGENOCRINIDA Springer, 1913 \\ Superfamily LECANOCRINACEA Springer, 1913 \\ Family MESPILOCRINIDAE Jaekel,1918
}

Genus MESPILOCRINUS De Koninck and Le Hon, 1854

Type species. Mespilocrinus forbesianus De Koninck and Le Hon, 1854, by the subsequent designation of Miller (1889).

Diagnosis. Small, subglobose crown with short arms that may be slightly twisted clockwise or anticlockwise from aboral view; primibrachial 2 axillary, secundibrachial 2 or 3 axillary; no radianal, CD basal enlarged with large anal $\mathrm{X}$ sitting above, outside the cup.

Remarks. All five nominal species, including the new species, of western European Mespilocrinus are reviewed. Additionally, six species from North America (Webster 2003) are included in a phylogenetic analysis of Mespilocrinus. These are: M. konincki (Hall, 1859) from the Kinderhookian Chouteau Limestone and Osagean Burlington Limestone; M. blairi (Miller and Gurley, 1895) from the Chouteau Limestone; M. chapmani Springer, 1920, from the Kinderhookian Maynes Creek Formation (F. Gahn, pers. comm. 2006) and the Osagean Burlington Limestone; M. thiemi Springer, 1920, from the Burlington Limestone; M. romingeri Springer, 1920, from the Osagean New Providence Shale and Fort Payne Formation; and M. myllos Ausich, Goldstein and Yates, 2000, from the Osagean Muldraugh Formation.

Mespilocrinus forbesianus De Koninck and Le Hon, 1854

1854 Mespilocrinus forbesianus De Koninck and Le Hon, p. 112, pl. 2, fig. 1a-e.

1920 Mespilocrinus forbesianus De Koninck and Le Hon; Springer, p. 193, pl. 5, figs 1-3.

1943 Mespilocrinus forbesianus De Koninck and Le Hon; Ubaghs, p. 1, text-figs 1-10.

1954 Mespilocrinus forbesianus De Koninck and Le Hon; Wright, p. 177, pl. 47, fig. 11.

Specimens examined. NMS 1958.1.1619, hypotype, Coplow Knoll (Wright 1954, pl. 47, fig. 11). BMNH E 21586, paratype, Tournaisian, Yorkshire [sic] (Clitheroe or Bowland in Lancashire rather than Yorkshire). BMNH E 71026, non-type, Coplow Knoll, Westhead Collection.

Diagnosis. A species of Mespilocrinus with the top of the CD basal even with the tops of adjacent radials; infrabasals convex, exposed; no cup or arm torsion; primibrachial 1 smaller than underlying radial; maximum calyx width at the radials; two bifurcations per ray; columnals homeomorphic.

Remarks. Columnals normal, not spindle-shaped. The paratype is a small crown that resembles fig. 522.2 in Moore and Teichert (1978), as well as plates 2 and 6 in De Koninck and LeHon (1854). The specimen from Coplow Knoll in the Westhead Collection is a good-sized cup and column that is indeed an M. forbesianus. BMNH E 21586 was collected in the nineteenth century when Clitheroe and the Forest of Bowland were part of Yorkshire before they were included in Lancashire. In his 'Geology of Yorkshire', Phillips (1836) included many specimens collected from the Clitheroe and Forest of Bowland (or Bolland) regions (Ausich and Kammer 2006).

Occurrence. Tournaisian, lower Chadian. Coplow Knoll, Clitheroe, Lancashire (British Grid ref. SD 750 431) and, questionably, the Forest of Bowland, Lancashire.

\section{Mespilocrinus granifer De Koninck and LeHon, 1854 (nomen dubium)}

1854 Mespilocrinus granifer De Koninck and Le Hon, pl. 2, fig. $6 \mathrm{a}-\mathrm{c}$.

Remarks. Of this species only a single cup is known; it has five equal basals with no enlarged CD basal and a single anal plate in the cup. The specimen illustrated in De Koninck and LeHon (1854) is too poor to identify the genus and, consequently, this taxon is here considered a nomen dubium.

\section{Mespilocrinus depressus Wright, 1936}

1936 Mespilocrinus depressus Wright, p. 409, pl. 10, figs 2, 6; text-figs 36-37.

1939 Mespilocrinus depressus Wright; Wright, p. 62, pl. 5, figs 13 , 15; text-figs $81-82$.

1954 Mespilocrinus depressus Wright; Wright, p. 180, pl. 47 , figs $8,10,13,17-18,25$.

Specimens examined. NMS 1958.1.1651, holotype, no. 1 Bed, Seafield Tower Limestone, west of Kirkcaldy, Fife, Scotland (Wright 1954, pl. 47, figs 8, 17, 25; text-figs 100-101). NMS 1958.1.1652-1657, same bed and locality.

Diagnosis. A species of Mespilocrinus with the top of the CD basal even with the tops of adjacent radials; infrabasals concave, exposed; no cup or arm torsion; primibrachial 1 smaller than underlying radial; maximum calyx width at the radials; one bifurcation per ray; columnals unknown. 
Remarks. Mespilocrinus depressus has infrabasals that are depressed, not visible in side view. In contrast, M. pring$l e i$, also from the Lower Limestone Group, is larger and the infrabasals are not depressed.

Occurrence. Brigantian. Seafield Tower Limestone, Lower Limestone Formation, west of Kirkcaldy, Fife (British Grid ref. NT 279 896); Hurlet Limestone [ = St Monance White Limestone (MacGregor 1996)], Lower Limestone Formation, St Monance, Fife (NO 524 014).

\section{Mespilocrinus pringlei Wright, 1954}

1954 Mespilocrinus pringlei Wright, p. 178, pl. 47, figs 7, 9, 14-16, 19-24.

Specimens examined. NMS 1958.1.1633, holotype, no. 1 Bed, Invertiel, Fife (Wright 1954, pl. 47, figs 15, 20, 24, text-figs 102103). NMS 1958.1.1634-1640, same bed and locality. BMNH E 70985, non-type, Lower Limestone Group, Macbie Hill, Peeblesshire. BMNH E 15184-6, non-types, three cups, Lower Limestone Group, St Monance, Fife. BMNH E 2158-9, non-types, three cups, no. 1 Bed, Invertiel, Fife. All localities in Scotland.

Diagnosis. A species of Mespilocrinus with the top of the CD basal even with the tops of adjacent radials; infrabasals convex, exposed; no cup or arm torsion; primibrachial 1 smaller than underlying radial; maximum calyx width at the radials; one bifurcation per ray; columnals homeomorphic.

Remarks. This is a small species, the infrabasals are not depressed and are visible in side view, and the columnals have a distinct spindle shape.

Occurrence. Brigantian. no. 1 Bed, Lower Limestone Formation, Invertiel, Fife (British Grid ref. NT 265 900); Lower Limestone Formation, Macbie Hill, Scottish Borders (NT 185 515); Hurlet Limestone of Lower Limestone Formation, St Monance, Fife (NO 524 014); Lower Limestone Formation, Kirkaldy, Fife (NT 279 896); Lower Limestone Formation, Carlops, Scottish Borders (NT 160 559); Lower Limestone Formation, Broadstone near Beith, North Ayrshire (NS 363 532).

\section{Mespilocrinus wrighti sp. nov. Text-figure 1A-D; Table 3}

Derivation of name. In honour of V. Paul Wright (Cardiff University), who kindly led us to Mississippian localities in South Wales in 2003.

\section{Holotype. NMW 81.8G.6825.}

Diagnosis. Crown small, subglobose; maximum width at first axillary, primibrachial 2; infrabasals completely cov-
TABLE 3. Measurements (in $\mathrm{mm}$ ) of Mespilocrinus wrighti sp. nov., NMW 81·8G.6825, holotype.

\begin{tabular}{llll}
\hline Crown & Cup & Basal & Radial \\
H, W & H, W & $\begin{array}{l}\text { H, W } \\
\text { Ray }\end{array}$ & $\begin{array}{l}\text { H, W } \\
\text { B }\end{array}$ \\
\hline$>11 \cdot 2,11 \cdot 4^{*}$ & $2 \cdot 9,8 \cdot 9$ & $2 \cdot 0,3 \cdot 0$ & $2 \cdot 2,4 \cdot 4$ \\
\hline
\end{tabular}

* Crown widest at primibrachial 2.

ered; CD basal tapers upwards to support narrow anal $\mathrm{X}$ plate; radials and proximal primibrachials have a sinistral torsion in aboral view; radial facets plenary; primibrachial 1 larger than underlying radial; arms closely abutting; only one bifurcation per ray preserved, total number unknown; columnals unknown.

Description. Crown small, subglobose, maximum width at first axillary, primibrachial 2; aboral cup bowl shaped; infrabasals completely covered by stem attachment; basals mostly exposed, CD basal larger than others and tapers upwards where it supports a narrow anal $\mathrm{X}$ plate that is poorly preserved; radials twice as wide as high, radial facet plenary, nearly straight; no interradial/interbrachial plates; radials and proximal arms display a subtle sinistral torsion as viewed aborally with each adjacent plate sitting higher from A to $\mathrm{C}$ rays (D-E rays mostly covered); arms closely abutting; primibrachial 1 fixed in aboral cup; primibrachial 2 axillary, at least two secundibrachials, further bifurcations unknown. Columnals, a weathered proxistele only, too poorly preserved to determine if homeomorphic or spindle shaped.

Remarks. Most other species of Mespilocrinus have the infrabasals partly exposed, rather than completely covered as in M. wrighti sp. nov. and M. myllos. Moving from A to $\mathrm{C}$ rays, each radial sits higher than the previous one producing a subtle sinistral spiral in the cup plates, which contrasts with the dextral spiral in cup plates of M. konincki. The type species, M. forbesianus, has no spiral in the cup plates.

The only other Tournaisian Mespilocrinus from Europe is M. forbesianus; similar-aged species in North America include M. chapmani (late Kinderhookian-late Osagean), M. konincki (late Kinderhookian-early Osagean) and M. thiemi (early Osagean). All four have the infrabasals exposed around the stem attachment scar, unlike M. wrighti. In M. forbesianus, the radials are not spirally offset from one another, and the CD basal has parallel sides with the top horizontal and even with adjacent radials. Mespilocrinus konincki (see Springer 1920, pl. 5, figs 4-15) has an elongate and irregular-shaped anal $\mathrm{X}$ (pl. 5, figs 9a, 13b) similar to M. wrighti, but it differs in having the infrabasals clearly visible and the spiral offset pattern of the cup plates is reversed (pl. 5, figs 12, 13a-b). Both M. thiemi and M. chapmani have angustary facets and widely separated arms, unlike M. wrighti. 
Occurrence. Tournaisian (Ivorian). Blucks Pool Limestone, Bosherton area, near Linney Head on the Pembrokeshire coast (British Grid ref. SR 966 947). Adams et al. (2004) indicated that Ivorian rocks in South Pembrokeshire are the Blucks Pool Limestone, which supercedes the Black Rock Limestone in this region.

\section{PHYLOGENETIC ANALYSIS OF MESPILOCRINUS}

Mespilocrinus is currently known only from the Mississippian of Europe and North America with ten valid species (Table 4; M. granifer is here considered a nomen dubium). It is the oldest genus of the Mespilocrinidae, with all other genera restricted to the Pennsylvanian or Permian (Moore 1978). Choice of outgroup to determine character order for a phylogenetic analysis is, thus, from a different family. Springer (1920, p. 191) suggested that M. thiemi Springer, 1920, with its angustary facets, was derived from Pycnosaccus Angelin, 1878 by loss of the radianal. Therefore, Pycnosaccus, which ranges from the Upper Silurian to Upper Devonian (Moore 1978), was chosen as the outgroup, which here consists of the combined characters for P. scrobiculatus (Hisinger, 1840), P. nodulosus Angelin, 1878 and P. tenuibrachiatus Springer, 1920 from Moore (1978) (Table 4).

\section{Characters}

The following is a detailed discussion of characters and character coding used in the species-level phylogenetic analysis of Mespilocrinus. The data for this analysis

TABLE 4. Character matrix used in the phylogenetic analysis of Mespilocrinus with Pycnosaccus as the outgroup. See text for discussion of the 13 characters and their character states. Polymorphic character states listed in parentheses. Age ranges shown in Text-figure 2.

\begin{tabular}{ll}
\hline Taxon & Characters \\
\hline $\begin{array}{l}\text { Pycnosaccus Angelin, 1878 } \\
\text { M. blairi (Miller and Gurley, 1895) }\end{array}$ & 0000000000000 \\
$\begin{array}{l}\text { M. chapmani Springer, 1920 } \\
\text { M. depressus Wright, 1936 }\end{array}$ & 100001010121 ? \\
$\begin{array}{l}\text { M. forbesianus De Koninck and } \\
\text { LeHon, 1854 }\end{array}$ & 110101010121 ? \\
$\begin{array}{l}\text { M. konincki Hall, 1859 } \\
\text { M. myllos Ausich, Goldstein and }\end{array}$ & $10010101) 0010101111$ \\
Yates, 2000 & $1 ? 001001011 ? 0$ \\
$\begin{array}{l}\text { M. pringlei Wright, 1954 } \\
\text { M. romingeri Springer, 1920 }\end{array}$ & 1100010101211 \\
$\begin{array}{l}\text { M. thiemi Springer, 1920 } \\
\text { M. wrighti sp. nov. }\end{array}$ & 101000010121 ? \\
\hline
\end{tabular}

include 13 binary and multistate characters that are equally weighted and unordered (Table 4).

1. Radianal. All species of Mespilocrinus lack a radianal, contrary to Pycnosaccus. The absence of the radianal is judged to be the derived character state [0, present; 1 , absent].

2. CD basal. The CD basal is the largest basal in Mespilocrinus. In Pycnosaccus, the top of the CD basal is below the top of the radials because the anal X plate is within the aboral cup. In some species of Mespilocrinus the $\mathrm{CD}$ basal has pushed the anal X plate out of the cup, and the top of the CD basal is even with or above the top of the radials. Thus, this appears to be the derived character state [0, below top of radials; 1 , even with or above top of radials].

3. Cup torsion. Mespilocrinus is unusual in that some species display cup torsion that is either dextral (clockwise) or sinistral (anticlockwise), when viewed aborally. Pycnosaccus lacks torsion, so torsion must be derived in Mespilocrinus because only some species possess this character $[0$, none; 1 , dextral; 2 , sinistral].

4. Infrabasal circlet. Nearly all species of Mespilocrinus have a convex infrabasal circlet, except for $M$. depressus where it is concave $[0$, convex; 1 , concave].

5. Infrabasals visible. Most species of Mespilocrinus have some portion of the infrabasals visible, except for M. myllos and M. wrighti in which the infrabasals are completely covered by the stem attachment area [0, visible; 1 , covered].

6. Radial facets. The radial facets of Pycnosaccus are both curved and angustary. In Mespilocrinus the radial facets may range from clearly angustary and curved, e.g. M. thiemi, to curved, e.g. M. chapmani, to straight and plenary, e.g. M. forbesianus [0, curved or angustary; 1, straight, plenary].

7. Primibrachial 1 size. In all species of Mespilocrinus except M. wrighti, primibrachial 1 is smaller than the subjacent radial [0, smaller than radial; 1 , larger than radial].

8. Primibrachial axillary. In Pycnosaccus, primibrachial 1 is axillary, whereas in Mespilocrinus primibrachial 2 is axillary [0, one; 1 , two].

9. Maximum crown width. In Pycnosaccus and all species of Mespilocrinus except M. wrighti maximum crown width is at the top of the radials. In $M$. wrighti maximum width is at primibrachial 1 [0, at radials; 1 , at primibrachial 1].

10. Arm spacing. In Pycnosaccus, the arms are clearly separated with open spaces between them when closed, which is also true for some species of Mespilocrinus, e.g. M. thiemi. Most species of Mespilocrinus have closely abutted arms when closed, e.g. M. forbesianus [0, separated; 1 , closely abutted].

11. Bifurcations in line per ray. Bifurcations in line per ray are the maximum number of axillary plates in line on any given ray. Pycnosaccus has three bifurcations in line per ray, whereas species of Mespilocrinus have either two or one [0, three; 1 , two; 2 , one].

12. Arm torsion. In addition to cup torsion, some species of Mespilocrinus exhibit arm torsion, which is not directly linked to cup torsion. Two species exhibit dextral cup torsion, whereas six exhibit dextral arm torsion when viewed aborally. Sinistral arm torsion was not observed (M. wrighti with sinistral cup torsion does not preserve enough arm brachials to determine if torsion is present) [0, none; 1 , dextral]. 
13. Columnals. Mespilocrinus is unique among flexible crinoids in having elongate, spindle-shaped columnals below the typical disc-shaped columnals of the proxistele (Springer 1920, pl. 5) in four of its species: M. chapmani, M. konincki, M. pringlei and M. thiemi. Pycnosaccus columnals are disc shaped [0, disc shaped only; 1 , spindle shaped below proxistele].

\section{Methodology and results}

Parsimony-based character analysis was performed using PAUP $^{*}$ 4.0b10 (Swofford 2001) on 13 characters for ten species of Mespilocrinus and the outgroup Pycnosaccus. All characters are equally weighted and unordered. Polymorphism is coded as a multistate character (only one instance in character 3). An exhaustive search using the branch and bound option found a single tree with the shortest length of 19 steps (CI, 0.84; HI, 0.21; RI, 0.81; RC, 0.68) (Text-fig. 2).

The generation of a single tree by PAUP indicates that the character data (Table 4) are well ordered with a minimal amount of homoplasy, as indicated by the low value of HI. Interpreting the cladogram as a phylogeny suggests that Mespilocrinus was derived from Pycnosaccus by the loss of the radianal (character 1), the raising of the first axillary from primibrachial 1 to 2 (ch. 8 ), and the addi-

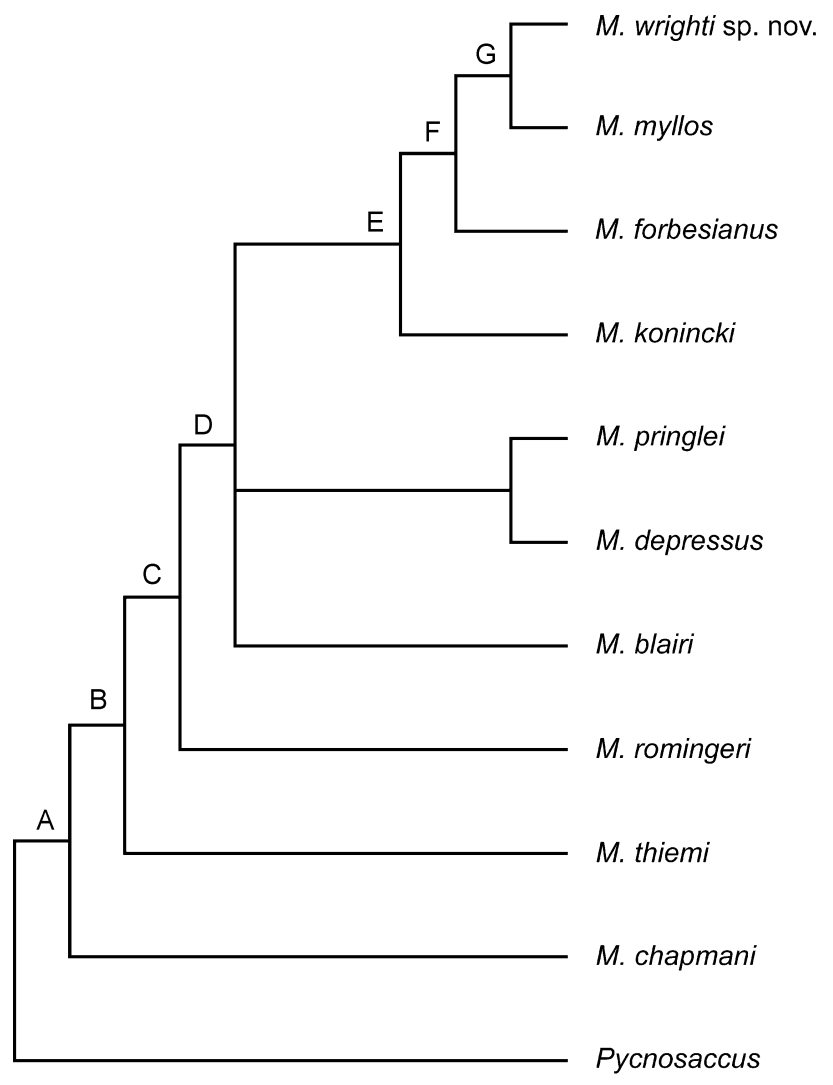

tion of spindle-shaped columnals (ch. 13) (node A in Text-fig. 2). The more primitive character states for Mespilocrinus include angustary or curved radial facets (ch. 6) and widely separated arms (ch. 10), as exhibited by M. chapmani and M. thiemi. Additionally, M. chapmani has at least three arm bifurcations per ray, similar to Pycnosaccus, whereas all other species have fewer arm bifurcations per ray with two bifurcations per ray in M. thiemi, M. romingeri, M. blairi, M. depressus and M. pringlei (node B in Text-fig. 2). The remaining taxa, M. konincki, M. forbesianus, M. myllos and M. wrighti, form a clade with only one bifurcation per ray (node $\mathrm{E}$ in Text-fig. 2).

The next synapomorphies to consider, as shown by the clade rooted by $M$. romingeri, include closely abutting arms (ch. 10) and dextral arm torsion (ch. 12) (node C in Text-fig. 2). This large clade of eight species, from $M$. romingeri to $M$. wrighti, consists entirely of species with the arms folded in tightly to form subglobose crowns, along with the loss of some characters and the addition of new characters in various combinations. Newly derived characters within this clade include dextral cup torsion (ch. 3) in M. romingeri; straight, plenary facets (ch. 6) in all but M. myllos (node D in Text-fig. 2); CD basal extends to the top or above adjacent radials (ch. 2) as in M. depressus, M. pringlei and M. forbesianus; loss

Time 3, Europe

Time 6, NA

Time 4, Europe

Times $1-4$, NA

Time 9, Europe

Time 9, Europe

Time 1, NA

Times 5-6, NA

Time 3, NA

Times 1-4, NA

Silurian-Devonian Europe and NA
TEXT-FIG. 2. Cladogram of the single most parsimonious tree of Mespilocrinus based on data in Table 4. Length, 19; CI, 0.84; HI, 0.21; RI, 0.81; RC, 0.68. Time units defined in Table 5. Important synapomorphies at nodes as follows: A, radianal lost, primibrachial 2 becomes axillary, spindle-shaped columnals; B, arm branching reduced from three to two bifurcations per ray; $\mathrm{C}$, arms become closely abutted with dextral arm torsion; D, radial facets become straight, plenary, rather than curved and angustary; E, arm branching reduced to one bifurcation per ray; F, loss of spindle-shaped columnals; G, infrabasals covered by stem attachment. 
of spindle-shaped columnals (node F in Text-fig. 2); infrabasals concave (ch. 4) as in M. depressus; infrabasals covered (ch. 5) as in M. myllos and M. wrighti (node G in Text-fig. 2); sinistral cup torsion (ch. 3), primibrachial 1 larger than the subjacent radial (ch. 7) and maximum crown width at primibrachial 1 (ch. 9) as in M. wrighti. Overall, M. wrighti is the most highly derived species of Mespilocrinus with the greatest number of character state changes (eight out of ten preserved) from the outgroup. It differs from all other species of the genus in having (1) sinistral cup torsion, (2) primibrachial 1 larger than the radials and (3) maximum crown width at primibrachial 1. Although it is highly derived relative to other species of Mespilocrinus, we judge that these differences are not sufficient to place it in a new genus.

The time ranges (Table 5) for the ten species of Mespilocrinus are plotted on the cladogram (Text-fig. 2). Although this single tree appears to be well ordered relative to character-state evolution, it is not well ordered stratigraphically. Basically, the time ranges for the different species appear to be randomly distributed, except that the two Time 9 species, M. pringlei and M. depressus, are grouped together. However, upon closer inspection there are discernible patterns that we interpret as follows.

1. The centre of evolution for Mespilocrinus was North America where three species appeared simultaneously in Time 1: M. chapmani, M. blairi and M. konincki. There are no species of Mespilocrinus from Time 1 in Western Europe, which may reflect the almost complete lack of preserved crinoids in this interval, the only species being Taxocrinus macrodactylus (Phillips. 1841) (Lane et al. 2001).

TABLE 5. Chronostratigraphic definition of time units for Mississippian crinoid occurrences in Europe and North America (Text-fig. 2), based on Leeder (1992), Jones (1996), Hance et al. (2002), Lane and Brenckle (2005) and Heckel and Clayton (2005).

\begin{tabular}{|c|c|c|}
\hline \multirow{2}{*}{$\begin{array}{l}\text { Time } \\
\text { unit }\end{array}$} & \multicolumn{2}{|l|}{ Chronostratigraphy } \\
\hline & Europe & North America \\
\hline 10 & Serpukhovian, Pendleian & Chesterian, late \\
\hline 9 & Visean, Brigantian & Chesterian, early \\
\hline 8 & Visean, Asbian & Meramecian, late \\
\hline 7 & Visean, Holkerian & Meramecian, early \\
\hline 6 & Visean, Arundian & $\begin{array}{l}\text { Osagean, latest (upper } \\
\text { Keokuk-lower Warsaw) }\end{array}$ \\
\hline 5 & Visean, late Chadian & $\begin{array}{l}\text { Osagean, late (lower } \\
\text { Keokuk) }\end{array}$ \\
\hline 4 & Tournaisian, early Chadian & Osagean, middle \\
\hline 3 & Tournaisian, Ivorian & Osagean, early \\
\hline 2 & Tournaisian, late Hastarian & Kinderhookian, latest \\
\hline 1 & Tournaisian, early Hastarian & Kinderhookian, late \\
\hline
\end{tabular}

2. Morphological disparity was achieved rapidly during Time 1, as shown by the widely spaced distribution of M. chapmani, M. blairi and M. konincki on the tree. This radiation event was part of the overall explosive radiation of crinoids following the Late Devonian mass extinction event when crinoids fell to their global minimum during the Frasnian (Baumiller 1994) and began recovering during the Famennian (Waters et al. 2003), followed by explosive radiation in the Tournaisian (Kammer and Ausich 2006).

3. The European and North American occurrences are chronostratigraphically mixed, indicating migration between these two areas, certainly from North America to Europe, but the reverse route cannot be ruled out (Kammer et al. 2007).

4. The European occurrences in Times 3, 4 and 9 correspond to the three highest times of crinoid generic richness in Western Europe during the Mississippian (Ausich and Kammer 2006). Thus, the limited occurrences in these time intervals are probably the taphonomic artefact of a fragmentary fossil record, thus adding to the stratigraphical incongruity of the tree.

5. Assuming there was a radiation during Time 1 , the relatively late appearances of $M$. thiemi and $M$. romingeri, between M. chapmani and M. blairi, may simply reflect non-preservation of an earlier origin for their lineages in North America. The same can be said for M. pringlei and M. depressus in Europe. The clade rooted by M. konincki shows only a modest stratigraphical incongruity with the slightly younger $M$. forbesianus, appearing before the older M. wrighti in Europe. Mespilocrinus is a small crinoid and was susceptible to disarticulation like many crinoids (Ausich and Sevastopulo 1994). Thus, it is reasonable to assume that the face-value record of Mespilocrinus may be biased by poor preservation.

Thus, the PAUP character analysis with one wellresolved tree for Mespilocrinus (Text-fig. 2) does appear to record a clear pattern of character evolution with reasonable stratigraphical congruity if a radiation is assumed during Time 1. The lack of stratigraphical order for some species is probably a taphonomic artefact of low taxonomic richness during Times 1, 2, 6 and 7 in western Europe (Ausich and Kammer 2006) or, in the case of North America, non-preservation of the origin of lineages.

\section{CONCLUSIONS}

Two new genera of advanced cladid crinoids are recognized among previously described species from Wales and England: Glamorganocrinus and Mendipocrinus. These new genera bring the total crinoid generic richness of the Ivorian of Western Europe to 36, 18 of which are advanced cladids. 
The new flexible crinoid species Mespilocrinus wrighti is described from the Ivorian of Wales. A phylogenetic analysis of ten species of Mespilocrinus, with Pycnosaccus as the outgroup, yielded a single tree. Mespilocrinus wrighti is the most highly derived species of the genus because of the greatest number of character state changes from the outgroup. Species time ranges and geographical occurrences, plotted on the tree, suggest that the centre of evolution for Mespilocrinus was in North America because three North American species widely spaced on the tree appeared simultaneously in the Kinderhookian (Time 1). This large morphological disparity achieved during Time 1 was part of the overall radiation of crinoids following the Late Devonian mass extinction event when crinoids fell to their global minimum during the Frasnian and began recovering during the Famennian, followed by explosive radiation in the Tournaisian. Species of Mespilocrinus were apparently able to migrate between North America and Europe, and possibly in the reverse direction. The lack of stratigraphical order for some species on the tree is probably a taphonomic artefact of low taxonomic richness during Times 1, 2, 6 and 7 in western Europe, or in the case of North America, non-preservation of the origin of lineages.

Acknowledgements. V. P. Wright (Cardiff University) guided us to several crinoid localities in Wales including Three Cliffs Bay, Gower. M. Howe (British Geological Survey, Keyworth) provided access to the collections and arranged for the loan of the type specimens of Mendipocrinus latifrons and Glamorganocrinus gowerensis. C. Howells (National Museum of Wales, Cardiff) provided access to the collections and arranged for the loan of the holotype of Mespilocrinus wrighti. This research was supported by the US National Science Foundation: EAR-0206307 (TWK) and EAR-02059068 (WIA). G. Sevastopulo and an anonymous reviewer improved an earlier draft of this manuscript.

\section{REFERENCES}

ADAMS, A. E., WRIGHT, V. P. and COSSEY, P. J. 2004. South Wales-Mendip Shelf. 393-475. In COSSEY, P. J., ADAMS, A. E., PURNell, M. A., Whiteley, M. J., WHYTE, M. A. and WRIGHT, V. P., (eds). British Lower Carboniferous stratigraphy. Joint Nature Conservation Committee, Peterborough, 617 pp.

ANGELIN, N. P. 1878. Iconographia Crinoideorum: in stratis Sueciae Siluricus fossilium. Samson and Wallin, Holmiae, $62 \mathrm{pp}$.

A USICH, W. I. 1998. Early phylogeny and subclass division of the Crinoidea (phylum Echinodermata). Journal of Paleonto$\log y$, 70, 499-510.

_ and KAMMER, T. W. 2006. Stratigraphic and geographic distribution of Mississippian (lower Carboniferous) Crinoidea from England and Wales. Proceedings of the Yorkshire Geological Society, 56, 91-109.
- and SEVASTOPUlO, G. D. 1994. Taphonomy of Lower Carboniferous crinoids from the Hook Head Formation, Ireland. Lethaia, 27, 245-256.

2001. The Lower Carboniferous (Tournaisian) crinoids from Hook Head, County Wexford, Ireland. Monograph of the Palaeontographical Society, 617, $136 \mathrm{pp}$.

- GOLDSTEIN, A. and YATES, R. 2000. Crinoids from the Muldraugh Member of the Borden Formation in northcentral Kentucky (Echinodermata, Lower Mississippian). Journal of Paleontology, 74, 1072-1082.

AUSTIN, T. and AUSTIN, T. Jr 1843-47. A monograph on Recent and fossil Crinoidea, with figures and descriptions of some Recent and fossil allied genera, 1-2, 1-32, pls 1-4, frontispiece $(1843) ; 3$, 33-48, pls 5-6 (1844); 4, 49-64, pls 7-8 (1845); 5, 65-80, pls 9-10 (1846); 6-8, 81-128, pls 11-16 (1847). London and Bristol.

BASSLER, R. S. and MOODEY, M. W. 1943. Bibliographic and faunal index of Paleozoic pelmatozoan echinoderms. Geological Society of America, Special Paper, 45, 734 pp.

BATHER, F. A. 1899. A phylogenetic classification of the Pelmatozoa. British Association of the Advancement of Science, Report, 1898, 916-923.

BAUMILLER, T. K. 1994. Patterns of dominance and extinction in the record of Paleozoic crinoids. 193-198. In DAVID, B., GUILlE, A., FERAL, J.-P. and ROUX, M. (eds). Echinoderms through time. Balkema, Rotterdam, 940 pp.

BURChetTE, T. P., WRIGHT, V. P. and FAULKNER, T. J. 1990. Oolitic sandbody depositional models and geometries, Mississippian of southwest Britain: implications for petroleum exploration in carbonate ramp settings. Sedimentary Geology, 68, 87-115.

DE KONINCK, L. G. and LE HON, H. 1854. Recherches sur les crinoïdes du terrain carbonifère de la Belgique. Mémoire de l'Académie Royale de Belgique, 28, 215 pp.

DONOVAN, S. K. 1986. An unusual crinoid column from Salt Hill Quarry, Clitheroe, Lancashire. Geological Journal, 21, 421424.

— 1992. A field guide to the fossil echinoderms of Coplow, Bellman and Salt Hill quarries, Clitheroe, Lancashire. North West Geologist, 2, 33-54.

— and SEVASTOPULO, G. D. 1985. Crinoid arms from Salt Hill Quarry, Clitheroe, Lancashire. Proceedings of the Yorkshire Geological Society, 45, 179-182.

_ 1988. Crinoid diversity around a Lower Carboniferous reef, Clitheroe, UK. 794. In BURKE, R. D., MLANDENOV, P. V., LAMBERT, P. and PARSLEY, R. L. (eds). Echinoderm biology: Proceedings of the Sixth International Echinoderm Conference. Balkema, Rotterdam, 818 pp.

_ and VELTKAMP, C. J. 1990. Barycrinus (Crinoidea) from the Lower Carboniferous of England. Journal of Paleontology, 64, 988-992.

_ and WESTHEAD, S. 1987. Platycrinites contractus (Gilbertson) and a new Platycrinites from the Lower Carboniferous of northern England. Proceedings of the Geologists' Association, 98, 211-215.

LEWIS, D. N. and HILL, D. 2005. Derbiocrinus diversus Wright from the Lower Carboniferous (Viséan, Asbian) of 
Derbyshire. Proceedings of the Yorkshire Geological Society, 55, 205-207.

HALL, J. 1859. Contributions to the palaeontology of Iowa, being descriptions of new species of Crinoidea and other fossils. Supplement to Volume 1, part 2, of the Geological Report of Iowa. Albany, New York, $92 \mathrm{pp}$.

HANCE, L., DEVUYST, F.-X. and POTY, E. 2002. Sequence stratigraphy of the Belgian Lower Carboniferous - tentative correlation with the British Isles. Canadian Society of Petroleum Geologists, Memoir, 19, 41-51.

HECKEL, P. and CLAYTON, G. 2005. Official names for the Carboniferous System. Geology Today, 21, 213-214.

HISINGER, W. 1840. Anteckningar i Physik och Geognosie under Resor uti Sverige och Norrige. Supplementum secundi continuatio. D. A. Norstedt et filii, Holmiae (Stockholm), 6 pp.

JAEKEL, O. 1918. Phylogenie und System der Pelmatozoen. Paläontologische Zeitschrift, 3, 1-128.

JONES, P. J. 1996. Carboniferous (Chart 5). 110-126. In YOUNG, G. C. and LAURIE, J. R. (eds). An Australian Phanerozoic timescale. Oxford University Press, Oxford, 279 pp.

KAMMER, T. W. and AUSICH, W. I. 1993. Advanced cladid crinoids from the Middle Mississippian of the east-central United States: intermediate-grade calyces. Journal of Paleontology, 67, 614-639.

— 2006. The 'Age of Crinoids': a Mississippian biodiversity spike coincident with widespread carbonate ramps. Palaios, 21, 238-248.

—— GOLDSTEIN, A. 2007. Gilmocrinus kentuckyensis n. sp. from the late Osagean (Mississippian) Muldraugh Member of the Borden Formation in Kentucky: a European immigrant originally derived from North America? Journal of Paleontology, 81, 209-212.

KIRK, E. 1941. Dinotocrinus, a new fossil inadunate crinoid genus. Proceedings of the United States National Museum, 89, 513-517.

- 1942. Rhopocrinus, a new fossil inadunate crinoid genus. Proceedings of the United States National Museum, 92, 151155.

— 1944. Aphelecrinus, a new inadunate crinoid genus from the Upper Mississippian. American Journal of Science, 242, 190-203.

LANE, H. R. and BRENCKLE, P. 2005. Type Mississippian subdivisions and biostratigraphic succession. 83-107. In HECKEL, P. H. (ed.). Stratigraphy and biostratigraphy of the Mississippian Subsystem (Carboniferous System) in its type region, the Mississippi River Valley of Illinois, Missouri, and Iowa. International Union of Geological Sciences, Subcommittee on Carboniferous Stratigraphy, Guidebook for Field Conference, St. Louis, Missouri, September 8-13, 2001. Illinois State Geological Survey, Guidebook 34 on CD, 108 pp.

LANE, N. G., MAPLES, C. G. and WATERS, J. A. 2001. Revision of Late Devonian (Famennian) and some Early Carboniferous (Tournaisian) crinoids and blastoids from the type Devonian area of North Devon. Palaeontology, 44, 1043-1080.

LAUDON, L. R. 1933. The stratigraphy and paleontology of the Gilmore City Formation of Iowa. University of Iowa Studies, 15, $74 \mathrm{pp}$.
LEEDER, M. R. 1992. Dinantian. 207-238. In DUFF, P. M. C. L. D. and SMITH, A. J. (eds). Geology of England and Wales. The Geological Society, London, $651 \mathrm{pp}$.

MAcGREGOR, A. R. 1996. Fife and Angus geology, an excursion guide. Third edition. Pentland Press, Edinburgh, 291 pp.

McINTOSH, G. C. 2001. Devonian cladid crinoids: families Glossocrinidae Goldring, 1923, and Rutkowskicrinidae new family. Journal of Paleontology, 75, 783-807.

MILLER, J. S. 1821. A natural history of the Crinoidea or lilyshaped animals, with observation on the genera Asterias, Euryale, Comatula, and Marsupites. Bryan \& Co, Bristol, 150 pp.

MILLER, S. A. 1889. North American geology and paleontology. Western Methodist Book Concern, Cincinnati, $664 \mathrm{pp}$.

— and GURLEY, W. F. E. 1895. New and interesting species of Palaeozoic fossils. Illinois State Museum, Bulletin, 7, 89 pp.

MITCHELL, M., STRANK, A. R. E., THORNBURY, B. M. and SEVASTOPULO, G. D. 1986. The distribution of platform conodonts, corals and foraminifera from the Black Rock Limestone (late Tournaisian and early Visean) of Tears Point, Gower, South Wales. Proceedings of the Yorkshire Geological Society, 46, 11-14.

MOORE, R. C. 1978. Flexibilia. T759-T812. In MOORE, R. C. and TEICHERT, C. (eds). Treatise on invertebrate paleontology, Part T, Echinodermata 2(2). Geological Society of America, Boulder, and University of Kansas Press, Lawrence, 1026 pp.

- and LAUDON, L. R. 1943. Evolution and classification of Paleozoic crinoids. Geological Society of America, Special Paper, 46, 734 pp.

_ and TEICHERT, C. (eds) 1978. Treatise on invertebrate paleontology, Part T, Echinodermata 2(2). Geological Society of America, Boulder, and University of Kansas Press, Lawrence, 1026 pp.

- STRIMPLE, H. L. and LANE, N. G. 1978. Suborder Poteriocrinina Jaeckel, 1918. T630-T754. In MOORE, R. C. and TEICHERT, C., (eds). Treatise on invertebrate paleontology, Part T, Echinodermata 2(2). Geological Society of America, Boulder, and University of Kansas Press, Lawrence, 1026 pp.

PHILLIPS, J. 1836. Illustrations of the geology of Yorkshire, or a description of the strata and organic remains. Part 2, The Mountain Limestone districts. Second edition. John Murray, London, 253 pp.

1841. Figures and descriptions of the Palaeozoic fossils of Cornwall, Devon, and West Somerset; observed in the course of the ordinance geological survey of that district. Longmans, Brown, Green, and Longmans, London, 232 pp.

SIMMS, M. J. and SEVASTOPULO, G. D. 1993. The origin of articulate crinoids. Palaeontology, 36, 91-109.

SLADEN, W. P. 1878. On the genus Poteriocrinus and allied forms. West Riding Geological and Polytechnical Society, Proceedings, New Series, 1, 242-253.

SPRINGER, F. 1913. Crinoidea. 173-243. In ZITTEL, K. A. von. Text-book of paleontology (translated and edited by C. R. EASTMAN). Second edition. Macmillian and Co., London, 1, 839 pp.

- 1920. The Crinoidea Flexibilia. Smithsonian Institution, Washington DC, Publication 2501, 486 pp. 
SW OFFORD, D. L. 2001. PAUP*: Phylogenetic Analysis Using Parsimony, version 4.0b10. Computer program distributed by Sinauer Associates, Inc., Sunderland, MA (http://www.paup. csit.fsu.edu).

UBAGHS, G. 1943. Note sur la morphologie, la biologie et la systématique du genre Mespilocrinus De Koninck et Le Hon. Bulletin du Musée Royal d'Histoire Naturelle de Belgique, 19, $1-16$.

1978. Skeletal morphology of fossil crinoids. T58-T216. In MOORE, R. C. and TEICHERT, C. (eds). Treatise on invertebrate paleontology, Part T, Echinodermata 2(1). Geological Society of America, Boulder, and University of Kansas Press, Lawrence, 1026 pp.

VAUGHAN, A. 1905. The palaeontological sequence in the Carboniferous Limestone of the Bristol area. Quarterly Journal of the Geological Society of London, 61, 181-307.

WACHSMUTH, C. and SPRINGER, F. 1880. Revision of the Palaeocrinoidea. Part 1, The families Ichthyocrinidae and Cyathocrinidae. Proceedings of the Academy of Natural Sciences of Philadelphia, 1879, 226-378.

- 1886. Revision of the Palaeocrinoidea. Part 3, Discussion of the classification and relations of the brachiate crinoids, and conclusion of the generic descriptions. Proceedings of the Academy of Natural Sciences of Philadelphia, 1886, 64226.

WATERS, J. A., MAPLES, C. G., LANE, N. G., MARCUS, S., LIAO, Z. T., LIU, L., HOU, H. F. and WANG, J. X. 2003. A quadrupling of Famennian pelmatozoan richness: new
Late Devonian blastoids and crinoids from northwest China. Journal of Paleontology, 77, 922-948.

WEBSTER, G. D. 2003. Bibliography and index of Paleozoic crinoids, coronates, and hemistreptocrinoids 1758-1999. Geological Society of America, Special Paper, 363. http:// crinoid.gsajournals.org/crinoidmod.

— and MAPLES, C. G. 2006. Cladid crinoid (Echinodermata) anal conditions: a terminology problem and proposed solution. Palaeontology, 49, 187-212.

WESTHEAD, S. 1979. Carboniferous crinoids from the Clitheroe area. Proceedings of the North-East Lancashire Group of the Geologists' Association, 2, 465-496.

WRIGHT, J. 1936. New Scottish Carboniferous crinoids. Geological Magazine, 73, 385-412.

1938. Anemetocrinus n. g. a five-armed poteriocrinid from the Lower Carboniferous limestones of Scotland. Geological Magazine, 75, 337-346.

1939. The Scottish Carboniferous Crinoidea. Transactions of the Royal Society of Edinburgh, 60, 1-78.

1950-60. The British Carboniferous Crinoidea. Monograph of the Palaeontographical Society, 1 (1), 1-24 (1950); 1 (2), 2546 (1951a); 1 (3), 47-102 (1951b); 1 (4), 103-148 (1952); 1 (5), 149-190 (1954); 2 (1), 191-254 (1955a); 2 (2), 255-272 (1955b); 2 (3), 273-306 (1956); 2 (4), 307-328 (1958); 2 (5), 329-347 (1960).

ZITTEL, K. A. von. 1895. Grundzüge der Paläontologie. Third edition. R. Oldenbourg, München/Berlin, 1, 608 pp. 